\title{
SOSIOLOGI VISUAL: SUATU PENDEKATAN ALTERNATIF DALAM PENINGKATAN HASIL PEMBELAJARAN SOSIOLOGI
}

\author{
Oleh: \\ Muhammad Iqbal* dan Trisni Handayani
}

\begin{abstract}
ABSTRAK
Penelitian ini menawarkan suatu konsep pembelajaran pada ilmu-ilmu sosial khususnya studi sosiologi agar lebih menarik dan kreatif, kenyataan yang terjadi pembelajaran untuk bidang ilmu sosial sering kali mengalami kekakuan dalam menjelaskan konsep maupun kasuistik. Pendekatan Sosiologi Visual digunakan untuk memvisualisasikan konsep menjadi sebuah realitas yang nyata berupa media gambar maupun film, sehingga akan dapat meningkatkan hasil pembelajaran. Dengan pendekatan ini juga maka setiap pengajar tidak akan mengalami kesulitan dalam mengajarkan studi sosiologi di sekolah maupun universitas.
\end{abstract}

Kata kunci : Sosiologi Visual, Pendekatan Alternatif, Hasil Pembelajaran

\section{PENDAHULUAN}

Pembelajaran terhadap Ilmu-ilmu Sosial, seperti sosiologi dan antropologi seringkali mengalami kekakuan (rigid) di sekolah-sekolah maupun universitas. Keadaan ini menunjukkan bahwa ketertarikan terhadap ilmu-ilmu sosial cenderung lebih rendah daripada ilmu-ilmu eksakta (alam). Ilmu-ilmu alam dapat diajarkan secara simulasi dan berbagai metode sehingga menarik bagi siswa maupun mahasiswa dalam memahami ilmu tersebut.

Sosiologi merupakan mata pelajaran yang diberikan ke siswa di sekolah sebagai upaya mengembangkan keterampilan dan pengetahuan tentang kemasyarakatan,yakni bagaimana berinteraksi, sosialisasi, mengelola konflik, dan dapat menganalisis permasalahan sosial beserta solusi yang diberikan. Oleh karena itu mata pelajaran sosiologi sangat penting dalam perubahan perilaku, individu maupun kelompok kea rah yang postif dan rasional terhadap perubahan sosial.

Pengamatan dilapangan dan beberapa penelitian menunjukkan bahwa pembelajaran sosial khususnya sosiologi di sekolah masih sarat hafalan dan bukan mengajarkan siswa untuk menganalisis dan mengonstruksi pola pikir siswa (Suarma, 1991:15)

Pada konteks kekinian proses pembelajaran lebih kepada pemusatan dari guru ke mahasiswa. Artinya guru menjadi 
fasilitaor bagi mahasiswa. Sehingga guru/pengajar bukan orang yang serba tahu namun bagaimana guru tersebut mendisain pembelajaran lebih menarik dan lebih kearah pemecahan masalah.

Posisi guru dalam proses pembelajaran sosiologi disekolah samakin penting terlebih pada era Teknologi, informasi, dan komunikasi (TIK). Guru dapat menggunakan berbagai media pembelajarannya secara kreatif dan inovatif seperti simulasi, gambar dan film, Sehingga siswa lebih mudah memahami materi dan konsep - konsep sosiologi secara integrasi dan solutif.

Keberhasilan dalam proses pembelajaran adalah tergantung kepada guru sebagai fasilitator dan siswa sebagai subyek yang terlibat dan memberi respon terhadap materi yang telah diberikan. Umpan balik yang sinergis akan menciptakan proses pembelajaran yang menyenangkan.

Namun fakta di lapangan, dalam pembelajaran sosiologi masih mengalami kekurangan pengajaran (teaching), salah satunya adalah pengajar yang tidak kreatif dalam mengajarkan konsepkonsep sosiologi dan minimnya media yang digunakan sebagai pengajaran. Selanjutnya, guru lebih mengedepankan aspek hafalan dan konseptual, sehingga berdasarkan pengamatan siswa sulit untuk menerima dan mata pelajaran sosiologi menjadi tidak menarik. Rendahnya hasil belajar pengantar sosiologi dapat dilihat pada tabel 1 .

Tabel 1. Rata-rata Nilai Ujian Akhir Semester

\begin{tabular}{|l|c|c|}
\hline \multirow{2}{*}{ No } & Tahun Akademik & Mata Kuliah Pengantar Sosiologi \\
\cline { 3 - 3 } & & Nilai \\
\hline 1 & $2006 / 2007$ & 60,0 \\
\hline 2 & $2007 / 2008$ & 65,0 \\
\hline 3 & $2008 / 2009$ & 64,0 \\
\hline
\end{tabular}

Oleh karena itu, penulis melakukan penelitian tindakan kelas, untuk melihat bagaimana cara penggunaan sosiologi visual dan seberapa efektifkah pendekatan ini dilakukan dalam meningkatkan hasil pembelajaran sosiologi di program studi pendidikan antropologi Unimed?

\section{METODE PENELITIAN}

Penulis melakukan suatu penelitian tindakan kelas (PTK) pada mahasiswa jurusan pendidikan antropologi Unimed yang mengambil mata kuliah pengantar sosiologi pada semester berjalan 
selama 6 bulan (Agustus - Desember 2009) dengan metode observasi (pengamatan) dan rencana tindakan kelas.

Rencana tindakan kelas terdiri dari 3 (tiga) siklus, dimana siklus pertama melakukan observasi dan merumuskan masalah, siklus kedua pengujian dan monitoring, dan siklus ketiga evaluasi dan refleksi/rekomendasi hasil.

\section{PEMBAHASAN}

\section{Sosiologi visual pendekatan dalam pembelajaran sosiologi}

Sosiologi visual merupakan perpaduan penggunaan perangkat multimedia (audio-visual) dengan metode sosiologis. visualisasi yang dimaksud adalah pengajaran yang dilakukan,seperti menggunakan media gambar (foto) dan rekaman, film, dsb (www.visualsociology.org).

Penggunaan pendekatan ini sangat efektif dalam proses pembelajaran, sehingga mahasiswa dapat mengimplementasikan realitas sosial secara nyata. Selanjutnya, pembelajaran sosiologi diharapkan tidak hanya sebatas teoritis namun aplikatif dan menarik. Menurut Winataputra (2005:4), media pembelajaran yang baik dapat merangsang timbulnya proses mental pada diri mahasiswa.

Berkaitan dengan media pembelajaran hasil penelitian Heinieh (1977) menyatakan bahwa dalam penggunaan informasi melalui audio-visual sangat tinggi dalam menjelaskan suatu obyek yang konseptual dan abstrak. Sosiologi visual sangat penting dalam peningkatan hasil belajar sosiologi.

\section{Fungsi Media}

Media memiliki peranan fungsi yang penting dalam proses pembelajaran. Menurut Winata (2005) fungsi media adalah :

1. Penggunaan media merupakan sarana bantu untuk mewujudkan situasi belajar yang efektif.

2. Media pembelajaran sebagai salah satu komponen yang tidak berdiri sendiri tapi berhubungan dengan komponen lainnya dalam rangka menciptakan situasi belajar yang diharapkan.

3. Media pembelajaran dapat meningkatkan kualitas proses belajar-mengajar 
4. Media pemnbelajaran meletakkan dasar - dasar yang konkrit untuk berpikir.

\section{Hasil penggunaan sosiologi visual dalam pembelajaran}

Dalam melaksanakan penggunaan pendekatan sosiologi visual dalam pembelajaran dilakukan dengan 3 (tiga) siklus, dimana masing-masing siklus memiliki tahapan-tahapan yang harus dilaksanakan, seperti observasi, monitoring, evaluasi dan rekomendasi akhir.

Pada tahap awal siklus, pengajar membuat soal pre test dan post test untuk melihat sejauh mana pemahaman dan pengetahuan mahasiswa terhadap sosiologi. Selanjutnya melaksanakan tindakan dengan memberikan penjelasan pembelajaran sosiologi visual. Pada tahap akhir melakukan evaluasi apakah mahasiswa sudah beradaptasi terhadap pembelajaran sosiologi visual.

Pada tahap kedua siklus, mahasiswa sudah dituntut untuk dapat membuat suatu agenda kerja dalam menjelaskan konsepkonsep sosiologi secara visualisasi, berupa gambar dan film pendek. Pengajar juga memfasilitasi mahasiswa dan mengontrol setiap aktivitas pembelajaran yang berlangsung. Selanjutnya, mengadakan post test terhadap mahasiswa.

Tabel 2. Nilai post test I dan II

\begin{tabular}{|c|c|c|c|c|c|c|}
\hline Jenis Test & $\begin{array}{l}\text { Nilai } \\
\text { Rerata }\end{array}$ & $\begin{array}{c}\text { Jumlah } \\
\text { Mahasiswa }\end{array}$ & $\%$ & $\begin{array}{l}\text { Nilai } \\
\text { Rerata }\end{array}$ & $\begin{array}{c}\text { Jumlah } \\
\text { Mahasiswa }\end{array}$ & $\%$ \\
\hline Post tes I & 45,0 & 40 & 100 & 50,0 & 40 & 100 \\
\hline Post tes II & 70,5 & 40 & 100 & 10,5 & 40 & 100 \\
\hline
\end{tabular}

Gambar 1. Diagram hasil belajar

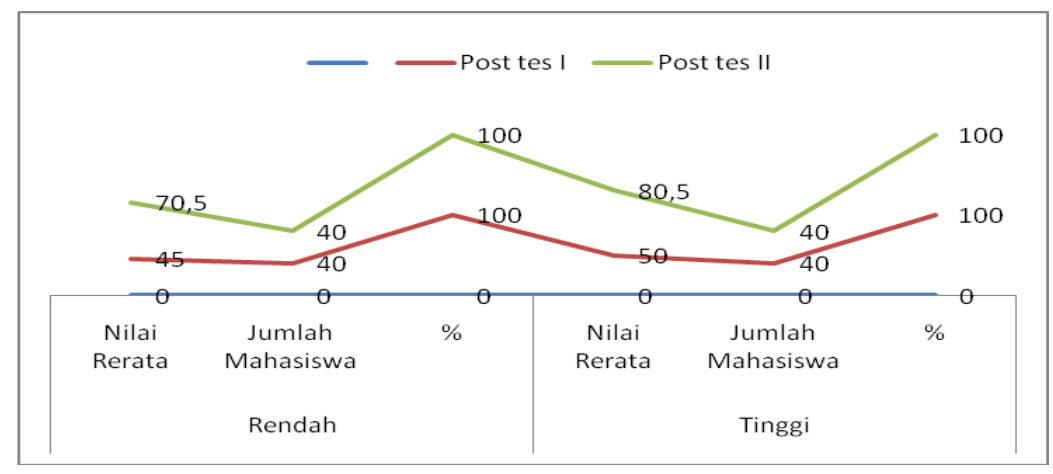

JUPIIS Volume 2 Nomor 2 Desember 2010 
Berdasarkan tabel 2 dan gambar 1 dapat dilihat bahwa terjadi peningkatan dalam hasil pembelajaran sosiologi pada siklus I dan II. Ini dapat dilihat pada siklus I rerata nilai 45.0 naik menjadi 5 point atau 50.0. selajutnya pada post test II nilai naik menjadi 10 point $(80,5)$. Pada siklus II peningkatan nilai sudah terlihat setelah menerapkan pembealajaran sosiologi visual. Kenaikkan tersebut belum signifikan dalam pencapaian hasil belajar yang memuaskan.

Pada tapa ketiga siklus, pengajar memberikan tugas membuat film pendek dengan menggunakan tema - tema sosiologi. Selanjutnya, pengajar kembali membuat strategi untuk mengatasi kekurangan dan kelemahan pada siklus II. Mahasiswa mempresentasikan hasil aktivitas yang dilakukan dan pengajar memberikan evaluasi pada mahasiswa.

Setelah melakukan post test pada siklus III dapat dilihat hasil pembelajaran yang dicapai pada tabel 3 dan diagram 2 .

Tabel 3. Nilai Post Test I,II,danIII

\begin{tabular}{|c|c|c|c|c|c|c|}
\hline Jenis Test & $\begin{array}{l}\text { Nilai } \\
\text { Rerata }\end{array}$ & $\begin{array}{c}\text { Jumlah } \\
\text { Mahasiswa }\end{array}$ & $\%$ & $\begin{array}{l}\text { Nilai } \\
\text { Rerata }\end{array}$ & $\begin{array}{l}\text { Jumlah } \\
\text { Mahasiswa }\end{array}$ & $\%$ \\
\hline Post tes I & 45,0 & 40 & 100 & 50,0 & 40 & 100 \\
\hline Post tes II & 7`0,5 & 40 & 100 & 75,5 & 40 & 100 \\
\hline Post tes III & 80,0 & 40 & 100 & 87,0 & 40 & 100 \\
\hline
\end{tabular}

Gambar 2. Diagram Hasil belajar

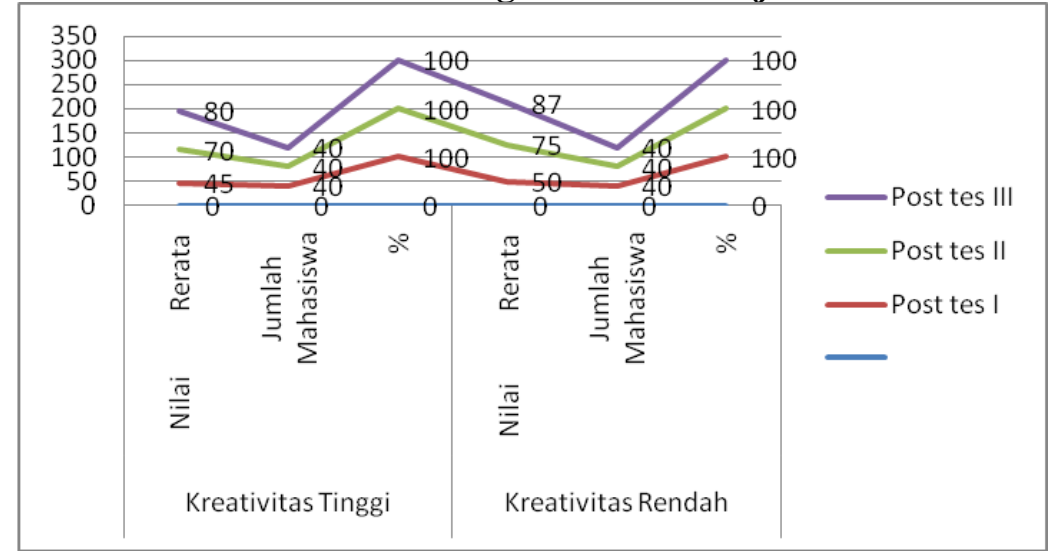


Jika kilta lihat pada tabel dan diagram diatas bahwa menunjukkan trend naik 7 point pada siklus ke tiga. Ini menggambarkan bahwa telah terjadi keberhasilan dalam proses pembelajaran dan pendekatan yang digunakan. Peneliti juga memprediksikan apabila pendekatan digunakan secara maksimal maka akan terjadi kenaikkan yang sangat signifikan. Secara keseluruhan siklus III menunjukkan keberhasilan dan peningkatan nilai mahaiswa dan tujuan pembelajaran tercapai.

Berdasarkan aktivitas belajar mahasiswa baik dari minat, tanggung jawab, kerjasama, dan kreatifitas menunjukkan bahwa pendekatan sosiologi visual meningkatkan mahasiwa dalam mengikuti pembelajaran sosiologi.

\section{PENUTUP}

Proses pembelajaran senantiasa berkembang dan mengalami dinamisasi. Dalam menerapakan suatu pendekatan harus diketahui kelemahan dan kelebihan dari pendekatan tersebut. Ini menggambarkan bahwa suatu pendekatan yang digunakan tepat atau tidak tepat diterapkan pada pembelajaran.

Penggunaan sosiologi visual sebagai pendekatan alternatif dalam pembelajaran sosiologi merupakan metode yang kreatif dan inovatif. Selain itu, mahasiswa dituntut untuk selalu update terhadap perkembangan software/hardware (IT) beserta metodologi sosiologi kontemporer. Menurut Arends (1997:156), model pembelajaran menumbuhkembangkan aktivitas belajar mahasiswa, baik secara individu maupun kelompok.sedangkan peranan dosen hanya sebagai fasilitator dalam mengajukan permasalahan, memberikan dorongan,, menyediakan bahan ajar,dsb. Keberhasilan mahasiswa mengatur pengetahuan mereka n sendiri sangat membantu mereka dalam memecahkan permasalahan dengan baik.

Hasil dalam penggunaan pendekatan ini diharapkan pembelajaran sosiologi lebih menyenangkan, komprehensif dan tidak monoton. Sehingga dosen dan mahasiswa dapat lebih mengimplementasi tema-tema sosiologi. Setelah pendekatan visualisasi diterapkan pada mata kuliah pengantar sosiologi maka menunjukkan antusiasme mahasiswa dan terjadi peningkatan nilai yang cukup signifikan. Bisa dapat digambarkan bahwa pendekatan ini sangat baik dijadikan model dalam pembelajaran pengantar sosiologi. 


\section{DAFTAR PUSTAKA}

Arikunto, S. 1997. Prosedur Penelitian Suatu Pendekatan Praktik. Rieneka Cipta, Jakarta

Gagne,M.R. 1977. The Condition of Learning, Rinehart and Winston, USA

Henslin. M James. 2006 .Sosiologi dengan Pendekatan Membumi, Penerbit Erlangga, Jakarta

Moleong J, Lexy.2005. Metode Penelitian Kualitatif.Rosda Press, Bandung

Rigeluth. 1983. Instructional design Theories anda Models: an Overview of Their Current Status, Lawrence Erelavan Associate, New Jersey

Sagala H. Syaiful. 2003. Konsep dan Makna Pembelajaran, Penerbit Alfabeta,Bandung

Trianto, 2009. Mendesain Model Pembelajaran Inovatif Progresif, Premada Media, Jakarta

Winata, Putra, S. Udin (dkk). 2005. Strategi Belajar Mengajar, UT, Jakarta

Wardhani,dkk. 2007. Penelitian Tindakan Kelas. UT, Jakarta

Website:

www.visualsociology.org diakses pada 26 Oktober 2009, pukul $19.30 \mathrm{Wib}$ 